\title{
Exploring the Determinants of Location Choice Decisions for Offshored
}

\section{R\&D Projects}

\author{
Peter Rodgers \\ School of Business, \\ University of Leicester, UK \\ Corresponding author Email: pwr3@1eicester.ac.uk \\ Zaheer Khan \\ Kent Business School, \\ University of Kent, UK \\ Email: z.khan-53@kent.ac.uk \\ ShlomoTarba \\ Birmingham Business School, \\ University of Birmingham, UK \\ Email: s.tarba@,bham.ac.uk
}

\author{
Assylbek Nurgabdeshov \\ Business School, \\ Suleyman Demirel University, Kazakhstan \\ Email: nurgabdeshov@gmail.com \\ Mohammad F. Ahammad \\ Leeds University Business School \\ Email: raselengland@gmail.com
}

Note: This is a pre-print post peer review accepted version. Please cite:

Rodgers, R., Khan, Z., Tarba, S., Nurgabdeshov, A., \& Ahammad, M.F. (2017). Exploring the Determinants of Location Choice Decisions for Offshored R\&D Projects, Journal of Business

Research, forthcoming. 


\begin{abstract}
This article extends the understanding of $\mathrm{R} \& \mathrm{D}$ offshoring with a particular micro-level focus on the determinants of location choice decisions for $R \& D$ activities at the project level. Using multinomial logistic regression, supplemented with PLS modeling, the article adopts an innovative R\&D project-level approach to examine the key determinants of the location choice decisions made by 126 UK-based MNEs. The findings demonstrate that project characteristics — such as speed, quality, interactivity, innovativeness, and routineness-have a greater impact on location choice decisions than traditional considerations such as cost and wage, which have been extensively examined. We further find that the classification of $R \& D$ projects is not one of the key determinants of $R \& D$ project location-related decisions. Theoretically, the article uses an approach proposed by Demirbag and Glaister (2010), combined with Dunning's OLI framework, to highlight the scope for utilizing integrated theoretical frameworks to investigate location choice decisions for R\&D offshoring within IB studies. We draw implications for research and practice.
\end{abstract}

Keywords: offshoring, R\&D, MNEs, location choice, determinant factors, microlevel factors 


\section{Introduction}

In recent decades, in response to the forces of globalization, multinational enterprises (MNEs) have increasingly engaged in offshoring their value chain activities (Contractor et al., 2010; Demirbag \& Glaister, 2010; Doh et al., 2009; Nieto \& Rodríguez, 2011), where 'offshoring' refers to the transnational relocation or dispersion of business activities that companies previously performed in their home countries, including captive (internal) and outsourced (external) delivery modes (Doh et al. 2009, p. 927). As a result of technological advances, of the digital revolution, and of the extraordinary fall in information and communication costs, scholars have witnessed not only a considerable growth in the volume of $R \& D$ project offshoring, but also changes in the nature and context of the MNE internationalization of knowledge-intensive R\&D activities (Atkinson, 2007; Demirbag \& Glaister, 2010; Lewin et al., 2009; Manning et al., 2008; Nieto \& Rodríguez, 2011; Steinberg et al., 2017). Companies have broadened the scope and complexity of their offshoring operations, taking advantage of the opportunities to employ, in their global value chains, high-skilled, low-wage employees operating across emerging markets (Blinder, 2006; Farrell, 2005). A clear pattern has emerged in which MNEs have shifted the geographical focus of their R\&D activities from developed economies across North America, Western Europe and Japan and are increasingly offshoring them to more low-cost countries within transforming economies in Eastern Europe, China, Russia and the emerging countries of Asia (Bunyaratavej et al., 2007; Huggins et al., 2007; Lewin et al., 2009).

Correspondingly, scholars have examined how MNEs engage in offshoring activities at the country, industry, firm, and managerial levels (see Clampit et al., 2015; Driffield et al., 2017; Hätönen and Eriksson, 2009; Lahiri, 2016; Oshri et al., 2015). Conventionally, companies try to keep control over their core activities, which provide them with competitive advantages in the market; however, the offshoring of core activities such as information 
technology (IT) and research and development (R\&D) (Steinberg et al., 2017) - the so-called knowledge intensive activities - is gradually increasing and becoming more geographically dispersed (Gammeltoft, 2005; Lewin et al., 2009; Nieto \& Rodríguez, 2011). According to Manning, Lewin, and Massini (2008), IT and new product development—including product design, engineering services, and $\mathrm{R} \& \mathrm{D}$ - have become the most frequently offshored firm activities. The recent literature on offshoring (Contractor et al., 2010; Hätönen and Eriksson, 2009; Clampit et al., 2015; Oshri et al., 2015; Lahiri, 2016; Manning et al., 2015; Pereira \& Malik, 2015) highlighted the increasing cross-fertilization of technologies across disciplines, the liberalization of markets, and the increased digitalization of value-creating activities, which all reduce the difficulties associated with managing distant operations. Moreover, in outlining the findings of a qualitative study of Indian IT companies, Malik, Sinha, Pereira \& Rowley (2017) demonstrated not only the theoretical utility of using the lenses of ambidexterity to examine offshoring processes, but also the importance of co-ordinating internal and external strategic choice ones. Together with the reduction of transaction and transportation costs, such factors have led to an overall increase in the offshoring of $R \& D$ activities (Contractor et al., 2010; Steinberg et al., 2017); however, it is important to recognize the inherent risks associated with it. In contrast to manufactured goods, which are only used after their production (Voss \& Hsuan, 2009), business functions such as R\&D activities are produced and consumed simultaneously, leading to increased chances of intentional and/or unintentional knowledge transfers, which may risk compromising a firm's competitive advantage. As a result of such potential for increased knowledge leakage within the business process, MNEs seeking to offshore their R\&D activities must appropriately consider the dangers of knowledge leakage in order to minimize the potential risks (Parida, Wincenta \& Oghazid, 2016). To this end, in a recent study, Mukherjee, Lahiri, Ash \& Gaur (2017) developed a classification scheme based on different knowledge search motivations 
(exploitation vs exploration) and degrees of local embeddedness, and suited to outline the potential knowledge outcomes of offshoring.

It is in this context that the current article aims to contribute to the extant offshoring literature within the field of International Business (IB). It does so by focussing its attention on the determinants of location choices for the offshoring of R\&D activities at the project level, zooming in on the micro aspects of individual project offshoring decisions. Within our existing knowledge of the determinants of location choice, scholarly attention has primarily focussed on country level factors such as the costs (Lewin \& Peeters, 2006), knowledge infrastructures, legal aspects (Demirbag \& Glaister, 2010; Demirbag, Tatoglu, \& Glaister, 2010), and political and economic risks pertaining to the host countries (Demirbag, McGuinness, \& Altay, 2010), and on the cultural distance between the MNEs' host and home countries (Bunyaratavej et al., 2007; Doh, Bunyaratavej, \& Hahn, 2009). Only relatively few studies have examined firm-level factors such as R\&D networking (Howells, 2008), firm growth strategies (Rilla \& Squicciarini, 2011), and economies of scale and scope (Blinder, 2006).

Within the paucity of studies examining, at the micro-level, the attributes of offshored services and their influence on location choice for the offshoring of activities, Doh et al. (2009) developed a theoretical framework suited to explore the offshoring of services by considering the latter's degree of interactiveness, repetitiveness, and innovativeness, which are in constant interaction with basic host country factors. Services involving high levels of interaction are often offshored to locations that benefit from higher levels of ICT infrastructure and a high usage of the home country language. In contrast, services that are highly repetitive tend to be offshored to locations characterised by relatively low wages and stable political environments. Zaheer et al. (2009) grouped the key dimensions of the tasks 
involved in service provision into three categories: system-intensive and routine, peopleintensive and routine, and people-intensive and creative. The authors suggested that companies tend to relocate specific services to clusters that possess higher levels of the specific capabilities required to undertake them. Similarly, Liu et al. (2011) categorized services with respect to their levels of interactiveness, routineness, and complexity. They argued that locations with good institutional environments are more attractive for the offshoring of non-routine, complex, and interactive services. Also, they showed that more routine, less complex, and less interactive services are offshored on a more regular basis.

Whilst these studies significantly contributed to our understanding of the processes, benefits, and risks involved in offshoring-related decisions, this article seeks to respond to Pisani and Ricart's (2016) assertion that "micro-level research on the management of geographically distributed work is one of the most promising areas for future investigations" (p.418) and strives to fill a gap in our understanding of the role played by the key determinants of $\mathrm{R} \& \mathrm{D}$ projects, particularly in relation to the individual project-level determinants of offshoring. Such a project-level fine slicing is important from the focal firm point of view, as it will enable companies to access knowledge through their alliance partners, removing the need to develop internal capabilities (e.g., Cantwell \& Mudambi, 2005). In this article, in response to the recognition that "examination of more micro firmlevel characteristics that undoubtedly affect the location and mode of offshoring projects ... may well add additional explanatory power to our analysis" (Doh et al., 2009, p.940), we conduct an in-depth, micro-level examination at the project level. Undertaking this nascent approach, this article is aimed at improving our existing understanding of the theoretical link between offshoring location choice and knowledge-intensive activities such as $R \& D$, particularly at the individual project level (e.g., Contractor et al., 2010, Demirbag \& Glaister, 2010). The existing studies focussed on understanding offshoring decisions by paying 
particular attention to cost-related factors, despite the fact that understanding individual project-related decisions is crucial to fully understanding the phenomenon of offshoring and the full range of risks associated with this form of cross-border business activity (Hahn et al., 2009). However, there is a lack of research on the determinants of location choices at the project level. As such, this article responds to Demirbag and Glaister's (2010, p.1558) call for a more fine-grained examination of those micro-level project characteristics that can enable an improved understanding of $R \& D$ project offshore location choice. Using multinomial logistic regression supplemented with PLS modelling, this article aims to fill this gap in the literature by outlining the findings of a study of the key determinants of location choices for R\&D offshoring at the project-level. It does so by using a unique set of primary data collected from 126 knowledge-intensive UK-based MNEs. The study's findings demonstrate that project characteristics such as speed, quality, interactivity, innovativeness, and routineness have a greater impact on location choices than traditional factors such as low-cost and wage considerations, which have been extensively examined. The article adds to the few studies that have explored the determinants of knowledge-intensive R\&D offshoring in three important ways: (1) by examining the determinants of the offshoring of R\&D-based projects; (2) by integrating arguments from transaction cost economics, resource-based view, and OLI paradigms and advancing the understanding of the determinants of $\mathrm{R} \& \mathrm{D}$ offshoring at the micro project level, thus providing a much fine-grained view of the determinants of knowledge-intensive activities; (3) by empirically providing quantitative insights into MNEs from the UK, thus potentially providing a scope for comparison and contrast with studies focussed upon the USA and other advanced economies.

The rest of the article is structured as follows. We commence by overviewing of our empirical study's theoretical framework, and follow up by reviewing the literature on offshoring of R\&D activities. We then outline the methodological issues within this research 
project. Next, we outline and discuss our research findings. Finally, we present the discussions and conclusions.

\section{Theoretical Background and Hypotheses Development}

Alongside the rapid emergence of offshoring within the global business environment, IB scholarship has held a healthy debate regarding the theoretical implications of offshoring (e.g., Contractor et al., 2010; Doh, 2005). While some scholars sought to adopt an economic geography perspective to explain the distribution of offshored services (Jensen \& Pederson, 2011) and used the internationalization process literature to explain the performance of offshored services (Hutzschenreuter et al., 2011), the transaction-cost economics perspective (TCE) (Williamson, 1981) was also extensively employed to explain offshoring (Ellram et al., 2008; Leiblein, et al., 2002; Murray \& Kotabe, 1999). TCE postulates that companies will choose the business alternatives that yield the lowest total running cost for their operations. Transaction cost theory also hypothesizes that companies will not offshore to areas characterised by a high potential risk of supplier opportunism. In particular, TCE has been used as a theoretical framework to explain governance mode decisions within offshoring (Manning et al., 2011) and optimal disaggregation-level decisions, especially in relation to the standardized, non-core activities that can be undertaken abroad in order to reduce costs (Murray \& Kotabe, 1999). However, scholars also noted the limitations of TCE's explanatory power. TCE cannot fully explain the complexities of offshoring-especially its internal resource, capability, and location aspects - particularly at the individual project-level, where a great deal of complexity is involved. As highlighted by Contractor et al. (2010, p.1428), "Transaction-cost theory, while useful for analyzing each 'internalization versus externalization' decisions, or analyzing each market entry mode choice, does not 
approach the puzzle of the firm as a global whole".

Responding to the increased offshoring of knowledge-intensive activities — such as R\&D ones-scholars (e.g., Lewin et al., 2009; Manning et al. 2008; Nieto \& Rodríguez, 2011; Steinberg et al., 2017) — sought to look beyond the TCE approach and employed the Resource-Based View (RBV) (Barney, 1991) to examine the capabilities and resources needed to achieve successful offshoring activities (Bunyaratavej et al., 2011; Javalgi et al. 2009). Offshoring can give a firm the opportunity to access valuable resources—including talented human capital, capabilities, and innovation-through which it can enhance its competitive position (Lewin et al., 2009). While the RBV's explanatory power may be relevant when companies have gained ownership advantages, it is limited in cases featuring higher levels of disaggregation, which may reduce firmspecific competencies and resources (Doh, 2005). Moreover, in an environment in which business functions are increasingly commoditized and modularized on a global scale (Baldwin \& Clark, 1997, 2000; Manning, 2013; Lew et al., 2016), this implicitly reduces the benefits gained from managing those resources and capabilities that should be rare and difficult to imitate (Barney, 1991). Acknowledging the individual limitations of the TCE and RBV approaches to the theorisation of offshoring, Kedia and Lehiri (2007) sought to combine these two theoretical lenses, using them to make useful distinctions between tactical and strategic offshoring decisions. Other scholars followed suit, using combined TCE and RBV approaches to better theorise offshoring activities (Boehe, 2010; Pereira \& Anderson 2012; Roza et al., 2011).

Similarly, Dunning's eclectic paradigm or 'OLI' framework (Dunning, 1980) has been used to investigate the importance of location choice for a firm's internationalization activities (Bunyaratavej et al., 2008; Chen, 2004; Demirbag \& Glaister 2010; Kedia \& 
Mukherjee, 2009; Kumar, 2001). 'OLI' stands for Ownership, Location, and Internalization, which represent three potential sources of competitive advantage that may impact on a firm's decision to internationalize its activities. Ownership advantages engage with why some companies internationalize and others do not. It suggests that specific firm-specific advantages may enable some companies to overcome the costs of operating overseas. Location advantages address the question of where a firm may choose to place its international activities. Finally, internalization advantages involve an examination of how a firm operates in a foreign country, trading off the savings in transactions, hold-up and monitoring costs of a wholly-owned subsidiary, against the advantages of other entry modes such as exports, licensing, or joint ventures. One of the key strengths of this approach is that it emphasises the incentives facing individual companies. However, responding specifically to the emerging patterns of R\&D activity across the globe and accepting the view, expressed by Chen (2004), that OLI advantages can be related to the technology routines of companies and to host countries, Demirbag and Glaister (2010) adopted an approach that took into account the importance of technology in order to better understand the relationship between location choice and the offshoring of R\&D activities. Moreover, the authors argued for the relevance of taking a value chain disaggregation perspective (Buckley \& Ghauri, 2004; Chen, 2004; Mudambi, 2008; Mudambi \& Venzin, 2010). In such a fashion, it is possible to examine the theoretical link between location choice and R\&D offshoring. As such, Demirbag and Glaister (2010) argued that MNEs will (re)locate some R\&D activities owing to the capabilities and resources found in a given geographical proximity, whilst, at the same time, exploiting its internalization and ownership advantages in order to maximize its competitive advantage (Buckley \& Ghauri, 2004; Chen, 2004). In this article, the offshoring of R\&D at the project level will be examined through the eclectic paradigm, 
taking into account the approach purported by Demirbag and Glaister (2010). The eclectic paradigm can be a useful lens to analyse the offshoring of the R\&D activities of MNEs by interpreting the ownership, internalization, and location advantages in the context of R\&D, with these advantages being related mainly to the technological routines and trajectories of the companies and host countries. We now turn our attention to the determinants of R\&D offshoring location choice.

\section{Determinants of R\&D offshoring location choice}

Within the offshoring context, Porter's (1985) 'value chain' concept often serves as a useful template. Analyzing the value chain involves disaggregating it into the specific activities that create value for customers. By disaggregating its value chain into discrete pieces - some to be performed at home, others to be offshored to different countries - $\mathrm{a}$ firm hopes to decrease its overall costs and risks. Recent research (Contractor et al., 2010, p.1419; Thakur, 2010) showed that companies are engaged in the micro-analysis and dissection of their value chains into slices finer than ever before. Value chains are no longer divided into large groupings such as $\mathrm{R} \& \mathrm{D}$, production, or marketing. The functions and operations within each category can be sliced into dozens or hundreds of subactivities or tasks. For each sub-activity or task, the question is then asked of where to perform it and of whether to perform it within the firm or outsource it (Contractor et al., 2010). Even R\&D, which is still considered a core activity that should not be offshored, can be disaggregated into various functions, keeping the sensitive ones in-house while offshoring the others.

Moreover, Jensen and Pedersen (2010) showed that companies rarely offshore an entire activity — like R\&D or IT — but only some of its tasks or sub-activities. The same research also demonstrated that, in the same value chain activity, some tasks can be 
relatively advanced and others relatively simple. For instance, in addition to its more advanced tasks-like basic or applied research-R\&D includes less advanced, standardized, and routine ones such as tests, patent application, and documentation (Jensen \& Pedersen, 2010). Based on the findings drawn from a recent panel dataset of 2421 active R\&D companies in Germany, Steinberg et al. (2017), showed how there are substantial variations in how captive and contract $R \& D$ offshoring strategies impact on innovation performance. Contract offshoring implies the outsourcing of a firm's R\&D activities to external, foreign companies, while captive offshoring involves a firm conducting its R\&D activities in its own foreign affiliates (Manning et al., 2008; Mudambi, 2008). At low degrees of offshoring, contract offshoring has a positive effect on innovation performance and is more beneficial. However, at larger degrees of offshoring, captive offshoring becomes more advantageous. Significantly, it is argued that, if they are over-employed, both offshoring strategies will, in time, have a negative effect on a firm's innovation performance. This aligns to Mihalache's (2012) findings, which emphasize that management should avoid excessive offshoring. As such, in this article, we argue that, in order to further extend our knowledge of R\&D offshoring, this stage of the location choice decision-making should be analysed based on the characteristics of the tasks or projects that will be offshored. In doing so, such a microlevel approach can enable a richer understanding of the offshoring strategies adopted by a firm.

Based on our conceptual model, outlined in Figure 1, this study proposes to look at the six different project level variables that could potentially influence the location choice decisions of R\&D offshoring.

INSERT FIGURE 1 HERE 
In this conceptual model, this study analyses the effects of classification, routineness, interactivity, innovativeness, and completion speed, and the quality of the R\&D projects being offshored to different locations (e.g., Demirbag \& Glaister, 2010). This represents a comprehensive view aimed at understanding offshoring-related decisions at the individual project-level, which will generate a much more fine-grained view of the specific determinants of knowledge-intensive activity offshoring decisions compared to traditional functional level offshoring related decisions.

While the fact that R\&D can be sliced into many constituent pieces and offshored to different locations has been discussed, the critical point here is which part of R\&D should be offshored to which location or country? In this context, the literature divides tasks or projects into core and non-core activities in order to determine whether and where to offshore each activity or to keep it in-house (Levy, 2005). According to the TCE and RBV theories, companies should keep their core activities or tasks at home to protect their core competencies. The offshoring of core activities may imply risks of knowledge leakage and loss of control. However, recent studies showed that companies have started to offshore their core activities. Contractor et al. (2010) explained this trend by redefining the concept of core and non-core activities. The authors argued that tasks can be divided into three categories.

(1) Core activities: those activities that a firm performs better than any other; should it give them to an external party, it would be creating a competitor or even sowing the seeds of its own dissolution.

(2) Essential activities: those activities that a firm needs to sustain its profit-making operations and that, if not performed exceptionally well, could place it at a competitive disadvantage or at risk; for example, logistics is a critical but non-core activity for a producer, but it is a core activity for a transportation firm. 
(3) Non-core activities: those activities that provide no competitive advantage. Such activities can be easily offshored and, in the short-term, are unlikely to seriously harm a firm.

Core versus Non-core activities. Previous studies identified three main motives for the offshoring of R\&D (Contractor et al., 2010). The first is saving by lowering operational costs, controlling cost, and freeing resources for more profitable activities. The second is related to process improvement and the need to concentrate on core competences to achieve flexible internal reorganization, to accelerate projects, to gain access to a flexible workforce, and to sharpen business focus. The third motive is capability enhancement, which includes obtaining access to internally unavailable highly skilled talent and improving service quality. Analyzing the concept of core and non-core activities with the motives of R\&D offshoring, it can be concluded that cost saving is the main motive and that the cost factor is the main determinant for the offshoring of non-core $R \& D$ activities. Consequently, it would be beneficial for MNEs to offshore the performing of a particular activity to an emerging or developing country due to the lower costs involved. MNEs are now simultaneously exploiting their internal firm-specific capabilities and becoming orchestrators of capability development and of the exploitation of their network partners on a global scale, thus maintaining control over the entire value chain (e.g., Mudambi \& Tallman, 2010; Mudambi, 2008). Location advantage can be conducive to cost and risk management advantages. Put differently, some countries have greater appeal in the form of availability of skilled workers and better national systems of innovation-as outlined through an OLI paradigm analysis - thus offering locational advantages to MNEs in spreading their core and non-core activities across the globe. MNEs will disperse noncore activities to those locations that offer cost advantages and in which the institutions are not well developed; this is because companies cannot rely on external forces to protect 
their core technologies due to the opportunistic behaviours of the actors involved in the management and completion of a particular activity, as per the TCE theory. Under such circumstances, MNEs will locate their core value chain activities to those locations that offer better protection of knowledge and possess knowledge infrastructures in terms of the availability of skilled workers and of well-functioning centres of excellence (e.g., Buckley \& Ghauri, 2004; Mudambi, 2008; Mudambi \& Venzin, 2010). Based on the above discussion, we hypothesize that:

Hypothesis 1: non-core R\&D projects are more likely than core ones to be offshored to developing and emerging countries.

Routineness. Routine and repetitive tasks can be accomplished by simply following sets of rules (Levy \& Murnane, 2012). The more a task can be specified by a set of rules, the easier it is to explain to third party suppliers without substantial misunderstanding, and the easier it is to control (Yu \& Levy, 2010). This points at the low transaction costs involved in the offshoring of routine activities. Dossani \& Kenney (2009) extended this argument and declared that transaction costs do not matter if companies offshore only routine $R \& D$ projects such as field tests and documentation. As routines activities may contain high proportions of explicit knowledge, which is easier to transfer than complex knowledge across value networks, MNEs are more likely to internalize complex tasks and keep them in-house (Kogut \& Zander, 1992), and spread less complex- routine activities to those locations in which where they can be performed on an optimal and low cost basis (e.g., Buckley \& Ghauri, 2004; Mudambi, 2008). Therefore, it can be concluded that, if a project is repetitive or routine, an MNE will benefit from offshoring it to an emerging or developing country. Hence, we argue that: 
Hypothesis 2: The more routine the $R \& D$ project, the greater the likelihood of an emerging or developing country being selected as its offshoring location.

Interactivity. Some service activities may require some degree of interaction between the provider and the customer. The success of any offshoring relationship involving a high degree of interactivity will depend on the ability of the parties to communicate effectively with each other. Speaking the same language and having the same business culture and mentality will substantially help improve service quality, reliability, and efficiency. Any misunderstanding between the offshoring firm and the service provider may prove costly to the former (Blinder, 2006; Doh et al., 2009). Thus, in order to avoid misunderstandings and improve efficiency, highly interactive R\&D tasks should be offshored to countries with close cultural or psychic distances to the home country. Thus:

Hypothesis 3: The more interactive the $R \& D$ project, the greater the likelihood of a country with closer cultural proximity with the home country being selected as an offshoring location for it.

Innovativeness. Lewin et al. (2009) reported that global hubs of innovation are developing in specific geographies around the world, many of which are still dependent on foreign participation and investment. The authors documented the increasing willingness of highly sophisticated companies to consider offshoring innovative activities to emerging markets such as India, China, and Eastern and Central Europe. They also mentioned that certain countries in Central and Eastern Europe as well as in South Asia specialize in attracting particular R\&D activities from companies based in specific regions of the world. Hence, it is suggested that innovation will influence the location of specific offshoring tasks. Projects such as basic and applied research, which are characterised by relatively high levels of innovation, require a strong knowledge infrastructure and a 
strong National Innovation System (NIS) (Lundvall et al., 2002). As a result, companies will seek to offshore these projects to countries that have such characteristics, rather than to emerging and developing countries with weak institutional environments (Khanna \& Palepu, 1997, 2006). Hence:

Hypothesis 4: The more innovative the $R \& D$ project, the lower the likelihood of emerging and developing countries being selected as $R \& D$ offshoring locations

Speed of project completion. Offshoring improves the speed of project completion by giving a firm access to large amounts of human capital (Carmel \& Schumacher, 2005). Offshoring-related speed is also achieved due to the availability of round-the-clock work hours across continents (Lewin et al., 2009). External sourcing through non-integrated suppliers also improves the speed of a firm's R\&D processes (Kessler, Bierly \& Gopalakrishnan, 2000). According to Quinn (2000), offshoring speeds up the innovation process-especially in high technology industries such as pharmaceuticals, biotechnology, and semiconductors - as suppliers have greater knowledge depth and innovate at a faster rate. Non-integrated suppliers located in emerging and developing countries can be faster due to their large dedicated teams of workers and also because they focus on a narrow range of activities (Holcomb \& Hitt, 2007). According to Contractor et al. (2010), speed of project completion is especially important for pharmaceutical and biotechnological R\&D projects, as they involve time costs, which are the costs incurred from lost sales opportunities due to any delays in the development of a drug or another important discovery in the presence of a ticking patent clock. As drug development is an extremely lengthy process, the time costs involved are very important to companies. Speed can be increased through offshoring due to the more lax regulations enforced by governments in emerging and developing countries (Bunyaratavej, Hahn, \& Doh, 2008). 
The duration of $R \& D$ projects also can be decreased as a result of the abundant supply of qualified R\&D personnel in emerging countries. Based on the preceding discussion, we advance the following hypothesis:

Hypothesis 5: The more crucial the completion speed of the $R \& D$ project, the greater the likelihood of emerging and developing countries being selected as $R \& D$ offshoring locations.

Quality of completed project. A trade-off between cost and quality is often involved in offshoring, especially in the service sector and in relation to emerging and developing countries. According to Bunyaratavej et al. (2007), companies often tend to assign greater importance to quality when facing intense competition at home. Some researchers who found quality to be an important determinant of offshoring, also found poor quality service to be one of the highest perceived risks of offshoring (Lewin \& Peeters, 2006). As evidenced in the study conducted by Levy (2005), the quality of projects offshored to emerging and developing countries is often a concern owing to the lack of face to face communication and to the low quality of the host countries' regulatory institutions. Some quality-related challenges of offshoring are the failure of foreign vendors to perform according to requirements, and their lack of competence (Perry \& Devinney, 1997). Quality can also be lower in offshoring due to the fact that a non-integrated supplier may be incentivised to save money by offering poor quality services and products (Embleton \& Wright, 1998). While such drawbacks may occur in both developed and emerging countries, the weakness of the latter's knowledge infrastructures and legal systems makes quality a greater concern in the offshoring of projects to them. Based on the above arguments, we postulate that: 
Hypothesis 6: The more important the quality of a completed $R \& D$ project, the lower the likelihood of emerging and developing countries being selected as $R \& D$ offshoring locations.

\section{Data and methodology}

The R\&D Scoreboard, which was published by the UK's Department for Business, Innovation \& Skills (BIS) in 2010, was used for this study. The Scoreboard is an international league table of the companies that are investing the most in $R \& D$. It is designed as a benchmarking tool for companies, investors, and policymakers. Fourteen leading business and professional organizations endorse the Scoreboard as a source of information for their companies and their shareholders when considering the amount to be invested in $\mathrm{R} \& \mathrm{D}$ as part of their innovation processes and business strategies. This report summarizes the 2009 data on investment in R\&D and financial performance of the 1,000 companies most active in R\&D in the UK (UK1000), including foreign-owned companies that conduct their R\&D in the UK. The majority of these MNEs were from the Software and Computer Services (15\%), and Pharmaceuticals and Biotechnology (13\%) sectors. MNEs from Banking and Financial services were excluded from this study taking into account the differences in the nature and type of their offshored R\&D projects and activities compared to manufacturing and IT related services.

At the initial stage of the data collection, the target respondents were sent an email stating the nature and purpose of the study, including all other relevant details. The respondents were also assured of complete data confidentiality with respect both to their identities and to those of the organizations they represented. The end of the email included a link to a web-based questionnaire designed to test the causal relationship 
between the dependent and independent variables from the conceptual model. To improve response rates, follow up calls were made and further emails were sent to the respondents.

Following the data collection, which started in January 2014 and finished by the end of March 2014, around 1,000 MNEs had been contacted. Responses were received from 142 respondents; of these, 126 were found to be usable, while the others were discarded for being invalid or for containing incomplete data. Each respondent gave information about two R\&D projects: one that had been offshored to foreign affiliates of the firm, and one that had been offshored to non-integrated suppliers. In total, detailed information was collected on 252 offshored $R \& D$ projects.

The scales used in the questionnaire had been selected following an extensive literature review; hence, they were pre-existing scales that, in some cases, had undergone slight adaptations for this particular study. Three academics and two senior level managers with significant experience of $R \& D$ project offshoring reviewed the contents of the questionnaire and provided feedback aimed at improving it. This test was conducted to determine whether the questions were sufficiently clear and whether the respondents would have any difficulty comprehending them. The questionnaire was thus modified to take into account some of the feedback received.

Common Method Bias and potential endogeneity. Given the fact that the study was to be single informant based and dealt with perceptual measures, it was essential to validate the findings in order to overcome any issues related to potential common method bias and potential endogeneity related issues. To reduce the possibility of such flaws, the questionnaire was constructed with different response formats, including a Likert scale, open ended questions, and fixed alternative questions. The independent and dependent variables were mixed up in the questionnaire, so that the respondents could not easily identify them. To further reduce the possibility of social desirability bias, the respondents were assured that 
both they and their organizations would remain anonymous as a post-hoc analysis (e.g., Podsakoff, MacKenzie \& Lee, 2003). Harman's one-factor test was performed with the principal component analyses of all Likert type measurement items, including both dependent and independent variables.

Non-response bias. To assess the potential presence of non-response bias within the data, a ttest (independent sample) was performed to check whether non-respondent and respondent companies differed in terms of a few related parameters such as their R\&D investments, operating profits, sales, and employees (Armstrong \& Overton, 1977). These figures were obtained from secondary data collected from firm websites and other online information sources. The results of the t-test suggested that there were no significant differences $(p<$ 0.05) between respondent and non-respondent companies with respect to the chosen parameters, indicating that the data did not present any issues in terms of non-response bias. In order to minimize retrospective bias-i.e., any possibility of distorted data or memory loss - the managers were asked to answer the questionnaire based on their experience of R\&D offshoring in the previous five years. The micro project level approach and the use of different regions as location choice for the dependent variable also reduced any potential endogeneity-related concerns. We also used relevant control variables in order to avoid potential endogeneity issues in our models. Lastly, the consistent Cronbach's Alpha values further confirmed the reliability and validity of the constructs used in this study, thus overcoming any potential reliability- and validity-related concerns.

\section{Measures}

Dependent variable (location of offshored $R \& D$ projects).

Rugman's (2005) definition of the Triad consisting of NAFTA, EU15, and Asia (extended ASEAN) was used for this study. Despite some criticisms, Rugman's definition of the Triad's regional boundaries provides a good foundation for further research on MNE 
R\&D location choice (Flores \& Aguilera, 2007). Although the logic behind the Triad concept was used in this study, it came with the awareness that the countries in each of the triad regions are not homogeneous. Therefore, the Asian countries were split into two clusters: 1) India \& China; and 2) the rest of the Asian Countries, including Japan, Taiwan, Singapore \& South Korea. Other clusters were: 3) USA, Canada \& Australia; 4) EU15 countries; and 5) Middle East, South America, Africa \& Russia. Therefore, R\&D offshoring host countries were grouped into regions along the lines suggested by Rugman (2005), but those that were heterogeneous were excluded. The rationales behind this were the inherited knowledge infrastructures and the similarities in science and engineering education in the clusters. Further, Mexico was excluded from the NAFTA group and Australia was included in it in order to render this group homogeneous as being made up solely of advanced economies. Also, the Asian countries were divided into two clusters in order to address issues of heterogeneity. According to Field (2009), in order to have reliable results from a multinomial logistic regression model, there should be at least 50 project data for each dependent variable. Since only 252 project data were collected from the MNEs, the maximum number of dependent variables is only 5. While the EU15; US; Canada \& Australia; Japan, Taiwan, Singapore \& South Korea; and China \& India clusters were constructed based on the framework of Rugman (2005), the last clusterMiddle East, South America, Africa \& Russia - which can also be called 'Others' was constructed because of the statistical restrictions of the model.

\section{Independent variables}

Project classification was measured by means of three items. The respondents were asked whether the offshored project had strategic value in terms of whether it served core or non-core functions in the firm's overall operations, improved its customer value, and drove its profits. Three items were also used to measure the project routineness variable. 
The respondents were asked to characterize the offshored project in terms of it being easy to codify, complex, and specific. Project interactivity was measured by means of five items related with project reciprocity, synchronicity, personalization, hypertextuality, and choice complexity. In order to measure project innovativeness, the respondents were asked about the level of new technology—both product- and process-related — involved in the offshored project and the innovativeness of its service features. Completed project quality was a two-item measure that included sustaining the quality of the project and improving it through sourcing strategies. Also, project completion speed was measured by using time and completion according to schedule dimensions.

\section{Results}

In order to test the hypotheses, we employed multinomial logistic regression (MLR) and partial least square (PLS) modelling to test the effects of the project-level factors on the R\&D offshoring location choice decisions of the selected MNEs. The control variables - such as firm size, age, and $R \& D$ size-were subjected to logarithmic transformation to address the skewness of the associated data. Offshoring type is a dichotomous control variable that indicates whether the project had been offshored to a foreign affiliate of the firm or to an external vendor. The results of multinomial logistic regression on the R\&D offshoring location choice of companies are presented in Table 1 and the marginal effects are shown in Table 2.

\section{INSERT TABLES 1 and 2 HERE}

The model presented in Table 1 has a high overall explanatory power with a highly significant chi square value $(\mathrm{p}<0.001)$. The $\mathrm{R}$-square measures confirm that the model has very good explanatory power $\left(\mathrm{R}^{2}: 0.517\right)$. The $\beta$-coefficients indicate the utility of selecting one region compared to the EU15 one. A positive coefficient of an independent variable for a 
group of countries indicates an increasing likelihood of that group being selected as an R\&D offshoring location, and a negative one indicates that the EU15 region has a higher probability of being selected than that group of countries.

Hypothesis 1 stated that, all other things being equal, the offshoring of non-core R\&D projects to developing and emerging countries is more likely to take place. However, the $\beta$ coefficients of dummy variables 1 (Core R\&D projects vs. Non-core R\&D projects) ($15.023, \mathrm{p}>0.1)$ and 2 (Essential R\&D projects vs. Non-core R\&D projects) $(1.488, \mathrm{p}>0.1)$ for the Middle East, South America, Africa \& Russia region were not statistically significant. Also, while the $\beta$-coefficient of dummy variable $1(6.030, \mathrm{p}<0.5)$ for India $\&$ China was significant, the $\beta$-coefficient of dummy variable $2(1.798, p>0.1)$ was not. Thus hypothesis 1 was not supported.

The project routineness related hypothesis received significant support. While the coefficient associated with the USA, Canada \& Australia $(\beta=-0.342, \mathrm{p}<0.1)$ region was significant and negative, both the coefficients for India \& China $(\beta=0.675, p<0.1)$, and for the Middle East, South America, Africa \& Russia $(\beta=0.595, \mathrm{p}<0.1)$ regions were significant and positive. The results for marginal effects, shown in Table 2, indicate that, as $R \& D$ project routineness increases, the likelihood of the USA, Canada \& Australia (5.86\%) and EU15 (12.42\%) regions being selected as offshoring locations decreases, while that of India \& China (3.13\%) and of the Middle East, South America, Africa \& Russia (3.72\%) regions increases, which confirms Hypothesis 2.

The $\beta$-coefficients for $R \& D$ project interactivity were negative and significant for the India \& China $(-0.434, \mathrm{p}<0.1)$ and for the Middle East, South America, Africa \& Russia ($0.740, \mathrm{p}<0.01)$ regions. The $\beta$-coefficient for the USA, Canada \& Australia $(1.777, \mathrm{p}<0.01)$ region was positive and significant. These findings support the hypothesis that, as $R \& D$ project interactivity increases, MNEs are more likely to engage in offshoring of $\mathrm{R} \& \mathrm{D}$ 
activities to regions which are culturally close to their home countries. As the home country of all the offshoring $R \& D$ projects investigated in this article was the UK, the logical result is that that the sample MNEs had all chosen the US, Canada \& Australia, and EU15 regions as R\&D offshoring locations instead of the India \& China and the Middle East, South America, Africa \& Russia ones. The marginal effects results, shown in Table 2, also confirm Hypothesis 3. The positive and significant $\beta$-coefficients found for the USA, Canada \& Australia, and EU15 regions, and the negative and significant ones found for the Middle East, South America, Africa \& Russia and India \& China regions indicate that, when MNEs from the UK engage in the offshoring of highly interactive R\&D projects, the probability of offshoring to the USA, Canada \& Australia, and EU15 regions increases, and that of offshoring to the India \& China and Middle East, South America, Africa \& Russia regions decreases.

Turning to $R \& D$ project innovativeness, the $\beta$-coefficients for the India and China (0.861, $\mathrm{p}<0.1)$ and the Middle East, South America, Africa \& Russia $(-0.829, \mathrm{p}<0.1)$ regions were all negative and significant. However, the coefficient for the USA, Canada \& Australia $(\beta=0.035, \mathrm{p}<0.1)$ region was positive and significant. These findings support Hypothesis 4, which proposes that as the $R \& D$ project innovativeness increases, the likelihood of emerging and developing countries being selected for offshoring by an MNE decreases. The marginal effects results, illustrated in Table 2 , imply that as $R \& D$ project innovativeness increases, the likelihood of the USA, Canada \& Australia and EU15 regions being chosen as an offshoring location increases by $11.77 \%$ and $1.89 \%$, respectively, while the likelihood of the India \& China and the Middle East, South America, Africa \& Russia regions being chosen decreases by $3.31 \%$ and $12.30 \%$ accordingly.

Similarly, Hypothesis 5, which is related to the effect of $R \& D$ project completion speed on location choice, received significant support in the model. The $\beta$-coefficients for the 
Japan, South Korea, Taiwan \& Singapore (1.560, p $<0.01)$, India and China $(3.786, p<$ 0.01), and Middle East, South America, Africa \& Russia $(1.078, \mathrm{p}<0.01)$ regions were all positive and significant. These findings demonstrate that, the faster the R\&D project needs to be completed, the more advantageous these countries — especially India \& China — become compared to the EU15. The marginal effects results, shown in Table 2, also support the hypothesis. When $R \& D$ project completion speed is an important criterion in offshoring, the probability of a new R\&D project being offshored to the Japan, South Korea, Taiwan \& Singapore (18.42\%) and India \& China (15.26\%) regions increases, while the probability of the same R\&D project being offshored to the USA, Canada \& Australia and EU15 regions decreases by $34.05 \%$ and $4.02 \%$, respectively. Overall, Hypothesis 5 is supported, confirming that $R \& D$ project completion speed is a major determinant of location choice for $\mathrm{R} \& \mathrm{D}$ offshoring companies.

Hypothesis 6 , relating to the effect of completed $R \& D$ project quality on location choice also received significant support. As the importance of completed $R \& D$ project quality increases for the companies, the likelihood of the Japan, South Korea, Taiwan \& Singapore $(\beta=-0.880, p<0.05)$, India \& China $(\beta=-1.047, p<0.05)$, and Middle East, South America, Africa \& Russia $(\beta=-0.792, \mathrm{p}<0.05)$ regions being selected as offshoring locations decreases compared to the EU15 region. The marginal effects results, shown in Table 2 , indicate that, if completed $R \& D$ project quality is a significant determinant for $\mathrm{R} \& \mathrm{D}$ offshoring location choice, the probability of being chosen increases for the USA, Canada \& Australia region $(18.72 \%)$, while it decreases for the Japan, South Korea, Taiwan \& Singapore region $(11.58 \%)$.

Regarding the control variables, firm age shows positive effects on location choice and $R \& D$ size shows negative ones, except for the India \& China region; however, the effects are not statistically significant. The $\beta$ coefficients for firm size were positive for the USA, 
Canada \& Australia region $(0.647, \mathrm{p}>0.1)$, and negative for the Japan, South Korea, Taiwan \& Singapore $(-0.625, \mathrm{p}>0.1)$, India \& China $(0.434, \mathrm{p}>0.1)$, and Middle East, South America, Africa \& Russia (- 0.053, p > 0.1) regions, but none were significant. The analysis of offshoring type indicated that MNEs prefer to offshore R\&D projects to external vendors in the India \& China $(\beta=-1.808, \mathrm{p}<0.01)$ and Middle East, South America, Africa \& Russia $(\beta=-0.807, \mathrm{p}>0.1)$ regions. The analysis also revealed that MNEs prefer the USA, Canada \& Australia $(\beta=0.431, \mathrm{p}>0.1)$ and Japan, South Korea, Taiwan \& Singapore $(\beta=$ $0.902, \mathrm{p}>0.1)$ regions for captive offshoring. However, the results were not statistically significant.

\section{PLS Path Modelling}

The primary criterion for the assessment of the structural model is R-square (Hair et al., 2012), which, in this case, is 0.5245 (Table 3). This indicates that $52.45 \%$ of the variance in the location choice of companies is explained by exogenous variables. The R-square values indicate a moderately strong PLS model (Chin, 1998).

\section{INSERT TABLE 3 HERE}

From Table 3, it can be seen that the path coefficients for $R \& D$ project completion speed and $R \& D$ project routineness are positive and significant. The multinomial logistic regression results indicate that, when $R \& D$ project completion speed and routineness are significant determinants of offshoring location choice, the likelihood of selecting the Japan, South Korea, Taiwan \& Singapore, India \& China, and Middle East, South America, Africa \& Russia regions increases, while that of selecting the USA, Canada \& Australia and EU15 regions decreases. For the location variable, the EU15 and USA, Canada \& Australia regions were labelled as 0 and 1 respectively, whereas the Japan, South Korea, Taiwan \& Singapore, India \& China, and Middle East, South America, Africa \& Russia regions were labelled as 2, 
3 and 4 accordingly. The results of the PLS modelling-which demonstrated the positive relationship between $R \& D$ project completion speed and routineness and location choicesupport those of the MLR modelling, which supports Hypotheses 2 and 5. According to the results of the MLR modelling, when $R \& D$ project quality, interactivity, and innovativeness are significant determinants of location choice, the likelihood of being selected increases for the USA, Canada \& Australia and EU15 regions, while it decreases for the Japan, South Korea, Taiwan \& Singapore, India \& China, and Middle East, South America, Africa \& Russia regions. The results of the PLS modelling indicate a negative relationship between $R \& D$ project quality, interactivity, and innovativeness and location choice. Based upon the labelling of the location variable, these outcomes also support the results of the MLR modelling, and support Hypotheses 3, 4, and 6. The results of the MLR modelling, shown in Table 1, indicate that Hypothesis 1 - which stated that, all other things being equal, non-core R\&D projects are more likely to be offshored to developing and emerging countries-is not supported. The PLS path modelling yielded the same result. The path coefficient for the $R \& D$ project classification variable was not statistically significant, which means that the relationship between $R \& D$ project classification and location choice of offshoring MNEs is not significant. These findings imply that Hypothesis 1 is not supported.

With regard to the control variables, the PLS modelling implies that there is a positive relationship between offshoring type and location, which indicates that MNEs prefer the USA, Canada \& Australia and EU15 regions for captive offshoring, and the Japan, South Korea, Taiwan \& Singapore, India \& China, and Middle East, South America, Africa \& Russia regions for external vendor offshoring. The PLS modelling showed the same results relating to firm size, $R \& D$ size, and age found in the MLR modelling, but none of them were statistically significant. 


\section{Discussion and Conclusions}

As a consequence of the growth of international business activity globalization processes, scholars have increasingly sought to improve our understanding of the phenomenon of offshoring (see Clampit et al., 2015; Demirbag \& Glaister, 2010; Doh et al., 2009; Hätönen and Eriksson, 2009; Lahiri, 2016; Oshri, Kotlarsky, Willcocks, 2015). By examining the under-researched micro-level aspects of individual R\&D project offshoring decisions, this article has sought to contribute to the extant offshoring literature by focussing its attention on the issue of location choice with particular regard to $R \& D$ activities. Its main aim was to analyse the effects of the key determinants of location choice for the offshoring of R\&D activities at the project level by means of a survey of 126 MNEs based in the UK. The findings suggest that R\&D project completion speed, quality, innovativeness, routineness, and interactivity affect location choice for R\&D offshoring, while $R \& D$ project classification is not significant for location choice.

In terms of $\mathrm{R} \& \mathrm{D}$ project completion speed, emerging countries are more advantageous relative to the EU15 region, and are therefore more likely to receive offshored R\&D projects. Moreover, this study also contributes to the location choice literature by identifying R\&D completed project quality as an important factor affecting $R \& D$ offshoring location choice. Therefore, due to the availability of relevant knowledge-related infrastructure in the EU15 region, an R\&D project is more likely to be offshored there than to emerging countries, which have weaker knowledge bases. A similar outcome is also observed with respect to the offshoring of innovative R\&D tasks; companies prefer to offshore innovative projects to developed economies rather than to emerging ones. Nevertheless, our findings indicate that companies prefer to offshore routine tasks to emerging economies; mostly to China, India, and the Middle East countries, among others. Also, the findings show that a highly interactive R\&D project from the UK is more likely to 
be offshored to the EU15 region than it is to the Middle East or China, but less likely than it is to be offshored to North America. This can be explained by taking into account that, whereas the cultural distance between the UK and the EU15 region is shorter than those between the UK and the Middle East or China, it is longer than that between the UK and the USA, Canada, or Australia. Importantly, our findings could not show any significant relationship between $R \& D$ project classification and location choice. No evidence was found of core activities being offshored preferably to developed countries and non-core ones to emerging countries. We used control variables to see whether R\&D project classification influenced location choice, but neither the MLS nor PLS modelling supported our expectations.

From a theoretical standpoint, this article has demonstrated the utility of using the approach proposed by Demirbag and Glaister (2010) - in combination with Dunning's OLI framework-in furthering the existing knowledge of the offshoring phenomenon. The transaction cost economics or resource based view approaches were extensively used in the extant literature to examine how MNEs engage in offshoring activities. However, these theories have often been viewed as having opposing propositions, especially in regard to offshoring. More recently, efforts have been made to synthesize these approaches within the study of offshoring. In this article, building upon Demirbag and Glaister (2010)'s study, we have used Dunning's eclectic paradigm to investigate the determinants of location choice. By using such an approach, we have expanded the scope for the utilisation of integrated theoretical frameworks to investigate location choices for R\&D offshoring within IB studies. Although the TCE, RBV, and OLI paradigms are useful frameworks to examine MNE location choices for the offshoring of R\&D activities, our findings indicate that the choice of a location for the offshoring of knowledge intensive $R \& D$ activities requires a perspective linked to all these theories. Regions, countries, and companies evolve from their existing 
routines and previous bases by gaining new advantages (sometimes bypassing some stages of R\&D and, hence, of technology development). Such a R\&D project offshore location choice perspective applied specifically to the OLI paradigm will help to explain why a certain location is chosen for $R \& D$ activities and also what types of $R \& D$ activities are offshored to particular countries. This extension may also enable researchers to examine the trade-offs made between OLI factors in the location choices for the offshoring of R\&D activities. Such an approach may create new avenues for research to test longitudinal changes in MNE knowledge creation strategies, the performance of different offshoring R\&D locations, and the impact on home country knowledge creation capacity. Finally, from a methodological perspective, we have used sophisticated and rigorous statistical techniques to address the questions pertaining to the gaps in the literature; in particular, we have used PLS pathmodelling techniques to confirm the multinomial logistic regression results. Also, while the majority of studies on offshoring utilised secondary data, we employed a unique primary data set to document the determinants of knowledge-intensive offshoring activities. Finally, in terms of managerial implications, while the offshoring of R\&D activities can provide MNEs with unique competitive advantages and access to foreign knowledge resources, and generate growth in innovative performance (Steinberg et al., 2017), our empirical findings demonstrate how companies clearly need to take into account a variety of micro-level factors - such as the types of projects being offshored-when deciding upon project offshoring locations. In particular, managers should take into account, for example, their home country's level of economic development (developed or emerging), and how companies from emerging economies are often less risk averse than those from more developed countries in terms of location choices (e.g., Duanmu, 2012). Moreover, managers need to take a proactive approach to ensure that R\&D activities are efficiently and timely embedded into their firm's wider innovation and business network strategies. 


\section{Limitations and Future Research Directions}

Firstly, this article's sole focus on UK-based MNEs can be considered a potential limitation; thus, future studies could extend the sample to include companies from other countries. Recently, companies from emerging economies have started to offshore some of their value chain activities to developed markets. As such, comparing companies from both developed and emerging economies and the determinants behind their decisions to offshore various activities could be a potential fruitful avenue for future research. Secondly, in this article, we did not examine the strategies adopted by companies control their partners' opportunistic behaviours or even to protect their existing knowledge. It would be useful for future research to analyse such strategies. Thirdly, it might be relevant to examine offshored project timings and how they affect location decisions. Fourthly, we did not examine the impact of R\&D offshoring on product, process and organizational innovation; thus, future studies could do so (e.g., Nieto \& Rodríguez, 2011). Finally, future studies may integrate cultural and institutional distances into their modelling in order to examine the impact of such factors on the location choice made for a particular project. 


\section{References}

Argyres, N. (1996). Evidence on the role of firm capabilities in vertical integration decisions. Strategic management journal, 17(2), 129-150.

Atkinson, R. D. (2007). The Globalization of $R \& D$ and Innovation: How do Companies Choose where to Build R\&D Facilities? Evidence provided before the U.S, House of Representatives Committee on Science and Technology, Subcommittee on Technology and Innovation, Washington, DC.

Baldwin, C. Y., \& Clark, K. B. (1997). Managing in an age of modularity. Harvard Business Review, 75 (5): 84-93.

Baldwin, C. Y., \& Clark, K. B. (2000). Design rules-the power of modularity. Cambridge, MA: MIT Press.

Barney, J. (1991). Firm resources and sustained competitive advantage. Journal of Management, 17(1), 99-120.

Barney, J. B. (2001). Is the resource-based "view" a useful perspective for strategic management research? Yes. Academy of Management Review, 26(1), 41-56.

Benito, G. R., Lunnan, R., \& Tomassen, S. (2011). Distant encounters of the third kind: Multinational companies locating divisional headquarters abroad. Journal of Management Studies, 48(2), 373-394.

Blinder, A. S. (2006). Offshoring: the next industrial revolution? Foreign affairs, 113128.

Boehe, D. M. (2010). Captive offshoring of new product development in Brazil: how does arbitrage influence local, collaborative relationships? Management International Review, 50(6), 747-773.

Buckley, P. J. and Ghauri, P. (2004). 'Globalisation, economic geography and the strategy of multinational enterprise'. Journal of International Business Studies, 35, 81-98.

Bunyaratavej, K., Doh, J., Hahn, E. D., Lewin, A. Y., \& Massini, S. (2011). Conceptual issues in services offshoring research: a multidisciplinary review. Group and Organization Management, 36(1), 70-102.

Bunyaratavej, K., Hahn, E. D., \& Doh, J. P. (2008). Multinational investment and host country development: Location efficiencies for services offshoring. Journal of World Business, 43(2), 227-242.

Bunyaratavej, K., Hahn, E. D., \& Doh, J. P. (2007). International offshoring of services: A parity study. Journal of International Management, 13(1), 7-21.

Carmel, E., \& Schumacher, P. (2005). Offshore strategy. In. Carmel, E. and Tjia, P. Offshoring Information Technology, Cambridge: Cambridge University Press.

Chen, C. H. (2004). 'Taiwanese IT firms' offshore R\&D in China and the connection with the global innovation network'. Research Policy, 33, 337-49.

Clampit, J., Kedia, B., Fabian, F. and Gaffney, N. (2015). Offshoring satisfaction: The role of partnership credibility and cultural complementarity. Journal of World Business, 50(1), 79-93.

Contractor, F. J., Kumar, V., Kundu, S. K., \& Pedersen, T. (2010). Reconceptualizing the firm in a world of outsourcing and offshoring: The organizational and geographical relocation of high-value firm functions. Journal of Management Studies, 47(8), 1417-1433.

Demirbag, M., \& Glaister, K. W. (2010). Factors determining offshore location choice for R\&D projects: A comparative study of developed and emerging regions. Journal of Management Studies, 47(8), 1534-1560. 
Demirbag, M., McGuinness, M., \& Altay, A. P. H. (2010). Perceptions of institutional environment and entry mode. Management International Review, 50(2), 207-240.

Demirbag, M., Tatoglu, E., \& Glaister, K. W. (2010). Institutional and transaction cost determinants of Turkish MNEs' location choice. International Marketing Review, 27(3), 272-294.

Doh, J. P., Bunyaratavej, K., \& Hahn, E. D. (2009). Separable but not equal: The location determinants of discrete services offshoring activities. Journal of International Business Studies, 926-943.

Doh, J. P. 2005. Offshore outsourcing: Implications for international business and strategic management theory and practice. Journal of Management Studies, 42(3): 695-704.

Dossani, R., \& Kenney, M. (2009). Service provision for the global economy: the evolving Indian experience. Review of policy research, 26(1-2), 77-104.

Driffield, N., Pereira, V., \& Temouri, Y. (2017). Does offshore outsourcing impact home employment? Evidence from service multinationals. Journal of Business Research. in press.

Duanmu, J.-L. (2012). Firm heterogeneity and location choice of Chinese multinational enterprises (MNEs). Journal of World Business, 47(1), 64-72.

Dunning, J. H. (1979). Explaining changing patterns of international production: in defence of the eclectic theory. Oxford bulletin of economics and statistics, 41(4), 269-295.

Dunning, J. H. (1980). Toward an eclectic theory of international production: Some empirical tests. Journal of International Business Studies, 11(1), 9-31.

Dunning, J. H. (1988). The eclectic paradigm of international production: A restatement and some possible extensions. Journal of International Business Studies, 19(1), 131.

Ellram, L. M., Tate, W. L., \& Billington, C. (2008). Offshore outsourcing of professional services: A transaction cost economics perspective. Journal of Operations Management, 26(2), 148-163.

Embleton, P. R., \& Wright, P. C. (1998). A practical guide to successful outsourcing. Empowerment in Organizations, 6(3), 94-106.

Farrell, D. (2005). Offshoring: Value creation through economic change. Journal of Management Studies, 42(3), 675-683.

Field, A. (2009). Discovering statistics using SPSS: Sage publications.

Flores, R. G., \& Aguilera, R. V. (2007). Globalization and location choice: an analysis of US multinational firms in 1980 and 2000. Journal of International Business Studies, 38(7), 1187-1210.

Gammeltoft, P. (2005). Internationalisation of $R \& D$ : trends, drivers, and managerial challenges. Paper presented at the Proceedings of the Druid Summer Conference on Dynamics of Industry and Innovation: Organizations, Networks and System.

Grant, R. M. (1991). The resource-based theory of competitive advantage: implications for strategy formulation. California management review, 33(3), 114-135.

Grant, R. M. (1996). Toward a knowledge-based theory of the firm. Strategic management journal, 17(S2), 109-122.

Hahn, E. D., Doh, J. P. and Bunyaratavej, K. (2009). 'The evolution of risk in information systems offshoring: the impact of home country risk, firm learning and competitive dynamics'. MIS Quarterly, 33, 1-20.

Hätönen, J., \& Eriksson, T. (2009). 30+ years of research and practice of outsourcingExploring the past and anticipating the future. Journal of International Management, 15(2), 142-155. 
Holcomb, T. R., \& Hitt, M. A. (2007). Toward a model of strategic outsourcing. Journal of Operations Management, 25(2), 464-481.

Howells, J. (2008). New directions in R\&D: current and prospective challenges. $R \& d$ Management, 38(3), 241-252.

Huggins, R., Demirbag, M. and Ratcheva, V. I. (2007). 'Global knowledge and R\&D foreign direct investment flows: recent patterns in Asia Pacific, Europe and North America'. International Review of Applied Economics, 21, 437-51.

Hutzschenreuter, T., Lewin, A. Y., \& Dresel, S. (2011). Governance modes for offshoring activities: a comparison of US and German firms. International Business Review, 20(3), 291-313.

Javalgi, R. G., Dixit, A., \& Scherer, R. F. (2009). Outsourcing to emerging markets: theoretical perspectives and policy implications. Journal of International Management, 15(2), 156-168.

Jensen, P. D. Ø., \& Pedersen, T. (2010). The Globalization of High-Value Activities: Why do firms offshore advanced tasks? Reshaping the Boundaries of the Firm in an Era of Global Interdependence, 5, 3.

Jensen, P. D. Ø., \& Pedersen, T. (2011). The economic geography of offshoring: the fit between activities and local context. Journal of Management Studies, 48(2), 352372.

Kedia, B. L., \& Lahiri, S. (2007). International outsourcing of services: a partnership model. Journal of International Management, 13(1), 22-37.

Kedia, B. L., \& Mukherjee, D. (2009). Understanding offshoring: a research framework based on disintegration, location and externalization advantages. Journal of World Business, 44(3), 250-261.

Kessler, E. H., Bierly, P. E., \& Gopalakrishnan, S. (2000). Internal vs. external learning in new product development: effects on speed, costs and competitive advantage. $R \& d$ Management, 30(3), 213-224.

Khanna, T., \& Palepu, K. (1997). Why focused strategies may be wrong for emerging markets. Harvard Business Review, 75(4), 41-48.

Khanna, T., \& Palepu, K.G. (2006). Emerging giants: Building world-class compaines in developing countries. Harvard Business Review, 84(10), 60-69.

Kogut, B. and Zander, U. (1992). Knowledge of the firm, combinative capabilities, and the replication of technology. Organization Science, 3(3), pp.383-397.

Kumar, N. (2001). 'Determinants of location of overseas R\&D activity of multinational enterprises: the case of US and Japanese corporations'. Research Policy, 30, 159-74.

Lahiri, S. (2016). Does Outsourcing Really Improve Firm Performance? Empirical Evidence and Research Agenda. International Journal of Management Reviews, 18(4), pp.464-497.

Langlois, R. N., \& Robertson, P. L. (1995). Firms. Markets, and Economic Change: A Dynamic Theory of Business Institutions, London.

Leiblein, M.J., Reuer, J.J. and Dalsace, F. (2002), "Do make or buy decisions matter? The influence of organizational governance on technological performance", Strategic Management Journal, Vol. 23 No. 9, pp. 817-833.

Levy, D. L. (2005). Offshoring in the new global political economy. Journal of Management Studies, 42(3), 685-693.

Levy, F., \& Murnane, R. J. (2012). The new division of labor: How computers are creating the next job market: Princeton University Press.

Lew, Y.K., Sinkovics, R.R., Yamin, M., \& Khan, Z., (2016). Trans-specialization understanding in international technology alliances: The influence of cultural distance. Journal of International Business Studies, 47(5), pp.577-594. 
Lewin, A. Y., Massini, S., \& Peeters, C. (2009). Why are companies offshoring innovation? The emerging global race for talent. Journal of International Business Studies, 901-925.

Lewin, A. Y., \& Peeters, C. (2006). Offshoring work: business hype or the onset of fundamental transformation? Long Range Planning, 39(3), 221-239.

Liu, R., Feils, D. J., \& Scholnick, B. (2011). Why are different services outsourced to different countries? Journal of International Business Studies, 42(4), 558-571.

Lockett, A., Thompson, S., \& Morgenstern, U. (2009). The development of the resource-based view of the firm: A critical appraisal. International Journal of Management Reviews, 11(1), 9-28.

Lundvall, B.Å., Johnson, B., Andersen, E.S. and Dalum, B. (2002). National systems of production, innovation and competence building. Research policy, 31(2), pp.213231.

Madhok, A. (2002). Reassessing the fundamentals and beyond: Ronald Coase, the transaction cost and resource-based theories of the firm and the institutional structure of production. Strategic management journal, 23(6), 535-550.

Madhok, A., \& Phene, A. (2001). The co-evolutional advantage: strategic management theory and the eclectic paradigm. International Journal of the Economics of Business, 8(2), 243-256.

Malik, A., Sinha, P., Pereira, V., \& Rowley, C. (2017). Implementing Global-local strategies in a post-GFC era: Creating an ambidextrous context through strategic choice and HRM. Journal of Business Research. in press.

Manning, S., Larsen, M.M. and Bharati, P., (2015). Global delivery models: The role of talent, speed and time zones in the global outsourcing industry. Journal of International Business Studies, 46(7), pp.850-877.

Manning, S. (2013). New Silicon Valleys or a new species? Commoditization of knowledge work and the rise of knowledge services clusters. Research Policy, 42(2), 379-390.

Manning, S., Lewin, A. Y., \& Schuerch, M. (2011). The stability of offshore outsourcing relationships. Management International Review, 51(3), 381-406.

Manning, S., Lewin, A., \& Massini, S. (2008). The globalization of innovation: a dynamic perspective on offshoring. Academy of Management Perspectives, 22(3), 35-54.

Maskell, P., Pedersen, T., Petersen, B., \& Dick-Nielsen, J. (2007). Learning paths to offshore outsourcing: from cost reduction to knowledge seeking. Industry and Innovation, 14(3), 239-257.

Mihalache, O.R., Jansen, J.J.P., Van den Bosch, F.A.J., Volberda, H.W. (2012). Offshoring and firm innovation: the moderating role of top management team attributes. Strategic Management Journal. 33 (13), 1480-1498.

Mudambi, R. (2008). Location, control and innovation in knowledge intensive industries'. Journal of Economic Geography, 8, 699-725.

Mudambi, R. and Venzin, M. (2010). 'The strategic nexus of offshoring and outsourcing decisions'. Journal of Management Studies, 47(8), pp.1510-1533.

Mudambi, S.M. and Tallman, S. (2010). Make, buy or ally? Theoretical perspectives on knowledge process outsourcing through alliances. Journal of Management Studies, 47(8), pp.1434-1456.

Mukherjee, D., Lahiri, S., Ash, S.R \& Gaur, A. S. (2017). Search motives, local embeddedness, and knowledge outcomes in offshoring. Journal of Business Research. in press.

Murray, J. Y., \& Kotabe, M. (1999). Sourcing strategies of US service companies: a modified transaction-cost analysis. Strategic Management Journal, 20(9), 791-809. 
Nieto, M.J., \& Rodríguez, A. (2011). Offshoring of R\&D: Looking abroad to improve innovation performance. Journal of International Business Studies, 42(3), 345-361.

Oshri, I, Kotlarsky, J, Willcocks, LP. (2015). The Handbook of Global Outsourcing and Offshoring, Palgrave MacMillan, London.

Parida, V., Wincenta, J., \& Oghazid, P. (2016). Transaction costs theory and coordinated safeguards investment in R\&D offshoring. Journal of Business Research, 69, 18231828

Pereira, V., and A. Malik. (2015). Human Capital Management in the Indian IT/BPO Industry. London: Palgrave Macmillan, London.

Pereira, V., \& Anderson, V. (2012). A longitudinal examination of HRM in a human resources offshoring (HRO) organization operating from India. Journal of World Business, 47(2), 223-231.

Perry, W., \& Devinney, S. (1997). Achieving quality outsourcing. Information Systems Management, 14(2), 23-26.

Pisani, N. and Ricart, J.E. (2016). Offshoring of services: a review of the literature and organizing framework. Management International Review, 56(3), 385-424.

Podsakoff, P. M., MacKenzie, S. B., \& Lee, J.-Y. (2003). Common method biases in behavioural research: A critical review of the literature and recommended remedies. Journal of Applied Psychology, 88 (5), 879-903.

Porter, M. E. (1985). Competitive advantage: creating and sustaining superior performance. 1985. New York: FreePress.

Priem, R. L., \& Butler, J. E. (2001a). Is the resource-based "view" a useful perspective for strategic management research? Academy of management review, 26(1), 22-40.

Priem, R. L., \& Butler, J. E. (2001b). Tautology in the resource-based view and the implications of externally determined resource value: Further comments. Academy of Management Review, 26(1), 57-66.

Quinn, J. B. (2000). Outsourcing innovation: the new engine of growth. MIT Sloan Management Review, 41(4), 13.

Rilla, N., \& Squicciarini, M. (2011). R\&D (re) location and offshore outsourcing: a management perspective. International Journal of Management Reviews, 13(4), 393-413.

Roza, M., Van den Bosch, F. A. J., \& Volberda, H. W. (2011). Offshoring strategy: motives, functions, locations, and governance modes of small, medium-sized and large firms. International Business Review, 20(3), 314-323.

Rugman, A. M. (2005). The regional multinationals: MNEs and'global'strategic management: Cambridge University Press.

Steinberg, P.J., Procher, V.D. and Urbig, D. (2017). Too much or too little of R\&D offshoring: The impact of captive offshoring and contract offshoring on innovation performance. Research Policy.

Stringfellow, A., Teagarden, M. B., \& Nie, W. (2008). Invisible costs in offshoring services work. Journal of Operations Management, 26(2), 164-179.

Thakur, P. (2010). Offshoring and outsourcing of core corporate activities: The global relocation of pharmaceutical industry clinical trials. Rutgers University-Graduate School-Newark.

Voss, C.A. and Hsuan, J. (2009). Service architecture and modularity. Decision

Sciences, 40(3), pp.541-569.

Williamson, O. E. (1981). The economics of organization: the transaction cost approach. American Journal of Sociology, 87(3), 548-577.

Yu, K. H., \& Levy, F. (2010). Offshoring professional services: institutions and professional control. British Journal of Industrial Relations, 48(4), 758-783. 
Zaheer, S., Lamin, A., \& Subramani, M. (2009). Cluster capabilities or ethnic ties? Location choice by foreign and domestic entrants in the services offshoring industry in India. Journal of International Business Studies, 40(6), 944-968. 


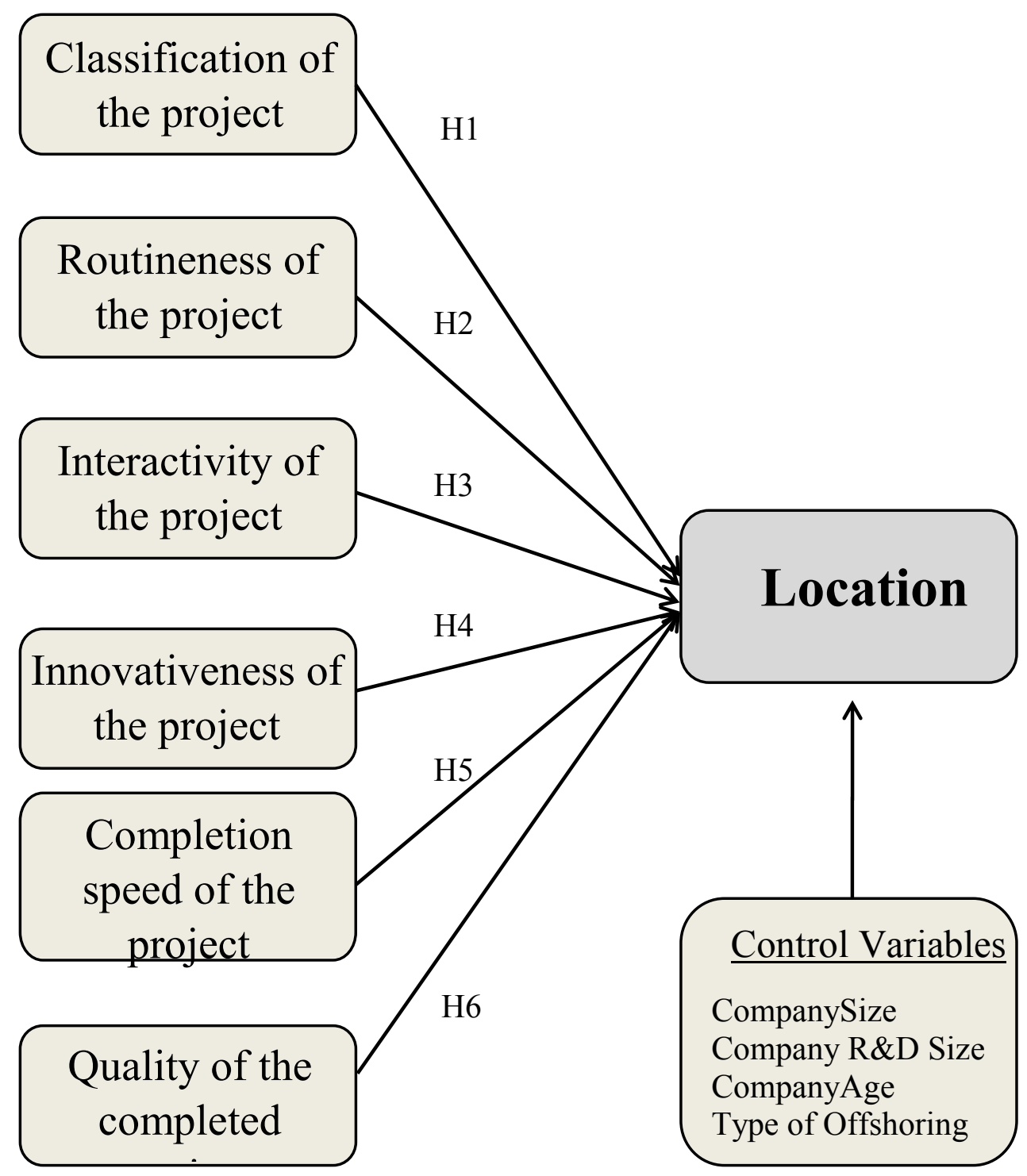

Figure XConceptual Model 
Table 1: Results for multinomial logistic model (reference group: EU15)

\begin{tabular}{|c|c|c|c|c|c|c|c|c|}
\hline \multicolumn{9}{|c|}{ Model with Control and Independent Variables } \\
\hline Variable & $\begin{array}{c}\text { USA, } \\
\text { Canada \& } \\
\text { Australia }\end{array}$ & S.E. & $\begin{array}{c}\text { Japan, S. } \\
\text { Korea, } \\
\text { Taiwan \& } \\
\text { Singapore }\end{array}$ & S.E. & $\begin{array}{c}\text { India \& } \\
\text { China }\end{array}$ & S.E. & $\begin{array}{c}\text { Middle } \\
\text { East, S. } \\
\text { America } \\
\text { \& Russia }\end{array}$ & S.E. \\
\hline Intercept & $-12.506^{* * *}$ & 3.816 & -4.422 & 3.421 & $-10.379^{* *}$ & 4.772 & 0.104 & 3.644 \\
\hline $\begin{array}{l}\text { Log of Firm } \\
\text { Size }\end{array}$ & 0.647 & .541 & -0.625 & .543 & -0.434 & .650 & -0.053 & .539 \\
\hline Log of R\&D Size & -0.218 & .540 & -0.234 & .571 & 0.103 & .653 & -0.105 & .573 \\
\hline Log of Firm Age & 0.794 & .742 & 0.520 & .772 & 0.452 & .871 & 0.808 & .809 \\
\hline $\begin{array}{l}\text { Speed of the } \\
\text { project }\end{array}$ & 0.182 & .315 & $1.560^{* \star *}$ & .329 & $3.786^{* \star *}$ & .646 & $1.078^{\star * *}$ & .334 \\
\hline $\begin{array}{l}\text { Quality of the } \\
\text { project }\end{array}$ & 0.138 & .394 & $-0.880^{\star *}$ & .354 & $-1.047^{* *}$ & .411 & $-0.792^{* *}$ & .348 \\
\hline $\begin{array}{l}\text { Routineness of the } \\
\text { project }\end{array}$ & $-0.342^{*}$ & .470 & 0.832 & .499 & $0.675^{*}$ & .607 & $0.595^{\star}$ & .522 \\
\hline $\begin{array}{l}\text { Interactivity of } \\
\text { the project }\end{array}$ & $1.777^{* * *}$ & .291 & -0.194 & .238 & $-0.434^{*}$ & .283 & $-0.740^{* \star *}$ & .267 \\
\hline $\begin{array}{l}\text { Innovativeness of } \\
\text { the project }\end{array}$ & $0.035^{*}$ & .525 & -0.228 & .586 & $-0.861^{*}$ & .624 & $-0.829^{*}$ & .576 \\
\hline $\begin{array}{l}\text { (Type } \\
\text { offshoring =0) }\end{array}$ & 0.431 & .644 & 0.902 & .668 & $-1.808^{* *}$ & .882 & -0.807 & .648 \\
\hline $\begin{array}{l}\text { (Type of } \\
\text { offshoring = 1) }\end{array}$ & $0^{a}$ & & $0^{a}$ & & $0^{a}$ & & $0^{a}$ & \\
\hline $\begin{array}{l}\text { (Classification of } \\
\text { the project }=1 \text { ) }\end{array}$ & 1.511 & 1.816 & 5.692 & 1.885 & $6.030^{* *}$ & 2.557 & -15.023 & 0.000 \\
\hline $\begin{array}{l}\text { (Classification of } \\
\text { the project }=2 \text { ) }\end{array}$ & 2.178 & 1.332 & 3.165 & 1.299 & 1.798 & 1.719 & 1.488 & 1.345 \\
\hline $\begin{array}{l}\text { (Classification of } \\
\text { the project }=3 \text { ) }\end{array}$ & $0^{a}$ & & $0^{a}$ & & $0^{a}$ & & $0^{a}$ & \\
\hline
\end{tabular}

$\mathrm{N}=252$; Log likelihood: - 190.155; $\mathrm{x}^{2}(44)=406.572 ;$ Prob. $\mathrm{x}^{2} \leq 0.001 ; \mathrm{R}^{2}=0.517$ $* * * \mathrm{p} \leq 0.01 ; * * \mathrm{p} \leq 0.05 ; * \mathrm{p} \leq 0.1$

a. This parameter is set to zero because it is redundant. 
Table 2: Marginal effects

\begin{tabular}{|c|c|c|c|c|c|}
\hline Variable name & EU15 & $\begin{array}{c}\text { USA, } \\
\text { Canada \& } \\
\text { Australia }\end{array}$ & $\begin{array}{c}\text { Japan, South } \\
\text { Korea, Taiwan } \\
\text { \& Singapore }\end{array}$ & $\begin{array}{c}\text { India \& } \\
\text { China }\end{array}$ & $\begin{array}{c}\text { Middle East, S. } \\
\text { America \& } \\
\text { Russia }\end{array}$ \\
\hline $\begin{array}{l}\text { Log of Firm } \\
\text { Size }\end{array}$ & 0.0447 & 0.0733 & -0.1278 & -0.0135 & 0.0233 \\
\hline Log of Firm Age & 0.0127 & -0.1734 & 0.0356 & 0.0103 & 0.1146 \\
\hline Type of offshoring ${ }^{a}$ & -0.0121 & -0.0225 & $-0.2252 * *$ & .0776 & $0.1823^{*}$ \\
\hline Speed of the project & $-0.0402 * *$ & $-0.3405^{* * *}$ & $0.1842 * * *$ & $0.1526^{* *}$ & 0.0438 \\
\hline Quality of the project & 0.0277 & $0.1872 * * *$ & $-0.1158 * *$ & -0.0260 & -0.0732 \\
\hline $\begin{array}{l}\text { Routineness of the } \\
\text { project }\end{array}$ & $-0.0586^{* *}$ & $-0.1242 *$ & 0.1143 & $0.0313 *$ & $0.0372 *$ \\
\hline $\begin{array}{l}\text { Interactivity of the } \\
\text { project }\end{array}$ & $0.0491 *$ & $0.1095 * * *$ & -0.0123 & $-0.0176^{*}$ & $-0.1286 * * *$ \\
\hline $\begin{array}{l}\text { Innovativeness of the } \\
\text { project }\end{array}$ & $0.0189 *$ & $0.1177 *$ & 0.0194 & $-0.0331 *$ & $-0.1230^{*}$ \\
\hline $\begin{array}{l}\text { Classification of the } \\
\text { project }\end{array}$ & 0.0490 & $0.4628 * *$ & $-0.4380 * * *$ & -0.0829 & 0.0091 \\
\hline
\end{tabular}

$\mathrm{N}=252 ; * * * \mathrm{p} \leq 0.001 ; * * \mathrm{p} \leq 0.01 ; * \mathrm{p} \leq 0.05$

Marginal effects are evaluated at the mean values of the explanatory variables. ${ }^{a} \mathrm{dy} / \mathrm{dx}$ is for discrete change of dummy variable from 0 to1. 
Table 3: PLS modelling with Location choice as the dependent variable - Model

\begin{tabular}{|l|c|c|c|}
\hline \multicolumn{1}{|c|}{ Variables } & PathCoefficients & $\begin{array}{c}\text { t-statistics (from } \\
\text { bootstrapping) }\end{array}$ & \multirow{2}{*}{$\mathbf{R}^{\mathbf{2}}$} \\
\hline Log of Firm Size & -0.0764 & 0.7093 & \\
\hline Log of R\&D Size & 0.0188 & 0.1898 & \\
\hline Log of Firm Age & 0.0150 & 0.2172 & \multirow{2}{*}{0.5245} \\
\hline Type of offshoring & 0.1664 & $1.6592^{*}$ & \\
\hline Speed of the project & 0.2167 & $2.4876^{* *}$ & \\
\hline Quality of the project & -0.1042 & $1.9781^{* *}$ & \\
\hline Routineness of the project & 0.2635 & $2.2870^{* *}$ & \\
\hline Interactivity of the project & -0.3595 & $4.8385^{* * *}$ & \\
\hline Innovativeness of the project & -0.0991 & $3.4813^{* * *}$ & \\
\hline Classification of the project & -0.0974 & 0.6928 & \\
\cline { 1 - 3 } & &
\end{tabular}

The path coefficients for the model are presented in Table 3, which shows that PLS results also do not differ from the results of multinomial logistic regression in Table 1. 
Appendix A: Characteristics of the sample

\begin{tabular}{|l|c|l|c|}
\hline Description & Percentage & Description & Percentage \\
\hline \multicolumn{2}{|c|}{ Industry - Sector } & \multicolumn{2}{c|}{ MNE age } \\
\hline Pharmaceuticals & 15.08 & $<20$ years & 20.63 \\
\hline Chemicals & 14.73 & $21-30$ years & 13.49 \\
\hline Electronics & 13.49 & $31-40$ years & 11.90 \\
\hline
\end{tabular}

\begin{tabular}{|c|c|c|c|}
\hline Software and Computer Services & 13.49 & $41-70$ years & 17.46 \\
\hline Biotechnology & 10.32 & $71-100$ years & 16.67 \\
\hline Motor Vehicles & 10.32 & $>100$ years & 19.84 \\
\hline Aerospace and Defence & 9.52 & \multicolumn{2}{|c|}{ Number of employees } \\
\hline Electrical Machinery & 7.94 & $<1000$ & 14.29 \\
\hline Telecommunication & 7.14 & $1000-5000$ & 24.60 \\
\hline Food Products & 4.76 & $5000-10000$ & 12.70 \\
\hline Metallurgy/ Mining & 4.76 & $10000-20000$ & 19.84 \\
\hline Computers and Office machines & 3.97 & $>20000$ & 28.57 \\
\hline Paper and Printing & 3.97 & \multicolumn{2}{|c|}{ Number of $R \& D$ employees } \\
\hline Plastic and Rubber & 3.97 & $<100$ & 17.46 \\
\hline Non-electrical machinery & 3.17 & $100-250$ & 20.63 \\
\hline Oil and Gas & 3.17 & $250-1000$ & 21.43 \\
\hline Ships and Boats & 0.79 & $1000-5000$ & 23.91 \\
\hline Textiles & 0.79 & $>5000$ & 16.67 \\
\hline
\end{tabular}




\begin{tabular}{|c|c|c|}
\hline Host region/ country & No. & Percentage \\
\hline $\begin{array}{c}\text { USA, Canada \& Australia } \\
\square \text { USA } \\
\square \text { Canada } \\
\square \text { Australia }\end{array}$ & $\begin{array}{c}61 \\
40 \\
7 \\
14\end{array}$ & 24.21 \\
\hline \begin{tabular}{ll}
\multicolumn{1}{l}{ EU15 } \\
$\square \quad$ Austria \\
$\square \quad$ Belgium \\
$\square \quad$ Denmark \\
$\square \quad$ Finland \\
$\square \quad$ France \\
$\square \quad$ Germany \\
$\square \quad$ Ireland \\
$\square \quad$ Italy \\
$\square \quad$ Netherlands \\
$\square \quad$ Norway \\
$\square \quad$ Spain \\
$\square \quad$ Sweden \\
$\square \quad$ Switzerland
\end{tabular} & $\begin{array}{c}\mathbf{6 1} \\
1 \\
5 \\
2 \\
1 \\
7 \\
15 \\
6 \\
2 \\
4 \\
1 \\
4 \\
6 \\
7\end{array}$ & 24.21 \\
\hline $\begin{array}{l}\text { Japan, Korea, Singapore \& Taiwan } \\
\quad \text { Japan } \\
\quad \text { Korea } \\
\quad \text { Singapore } \\
\quad \text { Taiwan }\end{array}$ & $\begin{array}{c}30 \\
11 \\
2 \\
10 \\
7\end{array}$ & 11.90 \\
\hline $\begin{array}{l}\text { India \& China } \\
\square \quad \text { India } \\
\square \quad \text { China }\end{array}$ & $\begin{array}{l}\mathbf{6 6} \\
36 \\
30\end{array}$ & 26.19 \\
\hline $\begin{array}{l}\text { Middle East, South America, Africa \& Russia } \\
\square \quad \text { Argentina } \\
\square \quad \text { Brazil } \\
\quad \text { Colombia } \\
\square \quad \text { Israel } \\
\square \quad \text { Mexico } \\
\square \quad \text { Pakistan } \\
\square \quad \text { Saudi Arabia } \\
\square \quad \text { South Africa } \\
\square \quad \text { Turkey } \\
\square \quad \text { United Arab Emirates } \\
\square \quad \text { Russia }\end{array}$ & $\begin{array}{c}33 \\
2 \\
7 \\
1 \\
1 \\
1 \\
1 \\
2 \\
4 \\
3 \\
4 \\
8\end{array}$ & 13.09 \\
\hline Total & 252 & 100.0 \\
\hline
\end{tabular}

